\title{
Ancient Festivals in Kütahya: A Narrative Research
}

\author{
Nil Dubana, Ramazan Yıldırım ${ }^{\mathrm{b}}$
}

\begin{abstract}
The aim of this research is to analyse the celebration of ancient festivals through narrations. The study is a qualitative research in which narrative research was employed. The study was carried out in Kütahya. The participants were selected using the snowball sampling technique which is a part of purposeful sampling. In the study, the data were collected through unstructured interviews, which are commonly used in narrative research. According to the results of the analysis, the festivals were examined as three themes: religious festivals, national festivals, and seasonal festivals. Preparations before the religious festivals include cleaning, shopping, and preparing meals. In the morning of the first festival day, fathers go to prayer with their sons. Then they visit cemetery. Women do not join these visits. In festival visits, guests are given socks and handkerchief. Preparations of national festivals begin long before. Streets are decorated with flags which signal the preparations. Celebrations mostly take place in stadiums. Reports showed that the celebrations of Nowruz are rare in Kütahya. Reports indicated that in Kütahya, Hıdırellez is much more frequently celebrated in contrast to Nowruz. Painting and clinking eggs are also seen in the celebration of Hıdırellez.
\end{abstract}

\section{Keywords}

Festival celebrations in Kütahya, religious festivals, national festivals, seasonal festivals, narration, tradition

Culture is the sum of material and spiritual elements taken from previous generations and transferred to next generations (Yamanlar 2000: 8). Turkish nation as the other nations has a unique culture in terms of language, history, literature, art, religion, music, architecture, legal perspective, and reactions to events (Gömeç 2006: 8).

Turkish people have tried to transfer their culture to next generations throughout their history. Their culture has varied following their sedentary life. Turkish culture has changed over time from the Uyghur State. It eventually became urban culture after a long period of steppe culture. Turkish people accepted Islam as their religious belief in the tenth century and followed their ancient traditions which were consistent with it (Güzel and Torun 2005).
One of the major cultural elements is feast. Among Turkish people, the concept of feast was first mentioned in Divan written by Kaşgarlı Mahmud in the eleventh century. Kaşgarlı stated that the original of the word is "bedhrem", which was used by Oghuz Turks as "beyrem". Kaşgarlı defined the concept as a "day of joy and fun" (Koca 2004: 25). It is known that all feasts are originated from either religious beliefs or a common past or traditions (Onarlı 2003). In Turkish

aAfyon Kocatepe University, Afyonkarahisar, Turkey bKütahya Yoncalı Vocational and Technical Anatolian High School, Kütahya, Turkey

\section{Correspondent Author:}

Nil Duban, Faculty of Education, Afyon Kocatepe University, ANS Campus, Afyonkarahisar, Turkey 
folklore, feasts and other types of recreations are significant. There are many types of feasts in Turkish culture which can be categorized into three major groups as follows: national, religious, and seasonal (Sakaoğlu and Alptekin 2004: 379).

Each nation has its own certain days and weeks which are either celebrated with joy or the remembrance of sad events. Such celebrations and remembrance strengthen national consciousness and reinforce the sense of common goals. A nation is a dynamic organism which can come together in both joy and sadness and share similar feelings. National celebrations and feasts actuate the dynamics of a society. Important days, local days, or national feasts are celebrated in Turkey (Akbulut 1995).

The first national feast of the Republic of Turkey was Hâkimiyet-i Milliye Festival. It was accepted on April 23, 1923 when the Turkish Grand Assembly was first opened. It has been devoted to Turkish children. In 1926, it was named as "Children's Day" and, from April 23, 1927, it was celebrated as "Children's Feast" (Özçelik 2011).

The feast of May 19 is another national feast. On May 19, 1919, Atatürk reached Samsun, a city on the Black Sea shore, to establish an organized national movement against the occupying forces. Local people in Samsun called that day as "Gazi's Day" in 1926. Then they tried to make it a national feast (Akbulut 1995). On June 20, 1938, it was called "Youth and Sports Day". In 1981, it was renamed as "19 May the Commemoration of Atatürk, Youth and Sports Day" (Uzun 2010).

A law proposal was given on February 2, 1925 to celebrate the day when the republic was established on October 29, and it was accepted by the National Grand Assembly on April 19, 1925.

The day following the Battle of Dumlupinar, August 30, was celebrated by Atatürk and other statesmen two years after the war. Atatürk made a significant speech there (Tanfer 1997). It became a national festival on April 1, 1926 in accordance with the law (No. 795).

The other type of festivals is religious ones. In Islam, there are two major festivals: festival of Ramadan and festival of sacrifice. These two festivals became a part of social life of Turkish people following their adherence to Islam. Each of these festivals has its own ritual, including praying and visiting to cemeteries and to other people. In festivals, people gather together and sing folk songs and dance (Artun 2011).

The last type is seasonal festivals. In Turkish culture, there are two examples, Nowruz and Hidirellez. Timing of these festivals depends on the movement of the sun (Çobanoğlu 2000). Nowruz is regarded as "New Year" or "Exit from Ergenekon" among Turkish people from East Turkistan to Balkans (Yildiz 2004: 37). More specifically, Nowruz is celebrated on March 21, which is considered to be the beginning of spring. It is also seen as the beginning of a new year. In a sense, the beginning of a new year is accepted to be March 21 in oral history (Özdemir 2006). Based on historical evidence, it is safe to argue that among Turkish people it is the beginning of a new year (Oğuz 2005). At the same time, it is seen as the day when Turkish people exited from Ergenekon. Turkish people have continued to celebrate Nowruz following their adherence to Islam and their establishment in Asia Minor. It was celebrated both in the Seljuk and Ottoman Empire periods (Yüksel 2011). Celebration of Nowruz includes various activities including entertainment, playing games, wearing new dress, giving gifts, visiting relatives, etc. (Uca 2007). In 2009, UNESCO (United Nations Educational, Scientific, and Cultural Organization) added Nowruz to the Intangible Cultural Heritage List (UNESCO 2009). In 2010, the United Nations accepted March 21 as the Nowruz day (United Nations 2010).

The other seasonal festival is Hidirellez. For Turkish people, it refers to the beginning of summer. It was integrated into their culture following their adherence to Islam (Günay 1995). They also think that 
Hidırellez refers to the day Hizır and Elias who reached eternity and came together. The term refers to the combination of the names "Hizır and İlyas (Elias)" (Aras 2002). Given that winter is hard for Turkish people, the beginning of summer is very significant. It is celebrated due to the fact that it refers to the beginning of a life, the revival of nature, and the flowering of plants (Araz et al. 1997). It is celebrated on May 6 every year and activities are related to wishes about healing, health, fertility, abundance, property, fortune, luck, and miracle (Turan 2008). On the Hidırellez day, people make wishes for having a house, being rich and successful, finding a lover, and recovering from illness. In order to reinforce their wishes, people also give alms, fasting, and sacrifices. Sacrifices are for the right of Hizır (Sezen 1992). Celebrations mostly occur in watery and greenery areas. This choice reflects ancestor cult of fire, water, and plant, and animal cults in the ancient belief system of Turkish people (Özdemir 1999).

Kütahya is a city in the Aegean Region of Turkey. The city was home for several nations and civilizations, including Hittites, Phrygians, Romans, the Byzantine Empire, the Seljuk Empire, Germiyanids, and the Ottoman Empire. Turks came Kütahya following the Battle of Manzikert at the end of the eleventh century. The city was the capital of Germiyanids. The city also witnessed the formation of the Ottoman State. The Battle of Dumlupinar also took place in the province (Kütahya Governorship 2016). The aim of this study is to analyse the celebration of ancient festivals through narrations.

\section{METHOD}

\section{Design}

The study is a qualitative research in which narrative research was employed. Narrative research includes personal narrations which may be told to the researcher or gathered from documents and archives
(Fraenkel, Wallen, and Hyun 2011). It has two categories: descriptive and explanatory. Descriptive narration analysis aims at describing the personal experience and cultural background (Sandelowski 1991).

\section{Participants}

The study was carried out in Kütahya. The participants were selected using the snowball sampling technique which is a part of purposeful sampling. In this technique, a qualified participant is asked to suggest others as participants. If the people suggested have the desired qualities, then they are added to the participant list. Until the desired number of participants is reached, the process of selection is continued (Christensen, Johnson, and Turner 2015: 172). In the study, eligibility criteria were developed as follows: older than the age of 50 and being a local resident of the city. The number of the participants was five, three males and two females. The code names of the participants are: Atakan, Doğru, Akpürüm, Yılmaz, and Erdinç.

\section{Data Collection Tool}

In the study, the data were collected through unstructured interviews, which are commonly used in narrative research. Such interviews may contain items about personal experience which is one of the significant data sources for narrative research (Connelly and Clandinin 1990).

\section{Data Collection}

The first interview was conducted with a participant with desired inclusion criteria. He was asked to suggest other people to interview them. Interviews were carried out in January 2016. Two interviews were held at the participants' home. The third one was at the interviewee's workplace. The interviews were recorded. It is suggested that recording of interviews makes it possible to analyse each detail (Merriam 2013: 105). Findings were presented with direct 
Table 1. Sub-themes and Categories of the Theme of Festivals

\begin{tabular}{|l|l|l|}
\hline Themes & Sub-themes & Categories \\
\hline \multirow{4}{*}{ Festivals } & \multirow{3}{*}{ Religious festivals } & Common cases \\
\cline { 2 - 3 } & & Specific cases for Ramadan festival \\
\cline { 2 - 3 } & \multirow{2}{*}{ National festivals } & Specific cases for sacrifice festival \\
\cline { 2 - 3 } & Seasonal festivals & Celebrations \\
\cline { 2 - 3 } & & Nowruz \\
\cline { 2 - 3 } & & Hidirellez \\
\hline
\end{tabular}

Table 2. Categories and Subcategories Under Religious Festivals

\begin{tabular}{|c|c|c|c|}
\hline Sub-themes & Categories & \multicolumn{2}{|l|}{ Subcategories } \\
\hline \multirow{10}{*}{$\begin{array}{l}\text { Religious } \\
\text { festivals }\end{array}$} & \multirow{5}{*}{ Common cases } & \multirow{3}{*}{ Preparation for festival } & Cleaning \\
\hline & & & Shopping \\
\hline & & & Food and beverage \\
\hline & & \multirow[t]{2}{*}{ Activities in the festival } & $\begin{array}{l}\text { Morning prayer on the first day of the festival } \\
\text { and cemetery visits }\end{array}$ \\
\hline & & & Hand-kissing and visits \\
\hline & \multirow{3}{*}{$\begin{array}{l}\text { Specific cases } \\
\text { for Ramadan } \\
\text { festival }\end{array}$} & Reading of Quran & \\
\hline & & Fasting breaking & \\
\hline & & Tarawih prayer & \\
\hline & \multirow{2}{*}{$\begin{array}{l}\text { Specific cases } \\
\text { for sacrifice } \\
\text { festival }\end{array}$} & Sacrificing & \\
\hline & & $\begin{array}{l}\text { Sending sacrificial ram to the home of the } \\
\text { future daughter-in-law }\end{array}$ & \\
\hline
\end{tabular}

quotes indicated by code names assigned to the related participants.

\section{Data Analysis}

The obtained data were first transcribed. The texts were read several times to find recurring patterns and themes. At the end, an analysis was done to reveal the place and events in the reports to develop codes (cited in Clandinin and Connelly 2000; Kear 2012). The events were grouped and marked based on the place, date, and topics. Then the codes were compared and the related themes and categories were developed.

\section{FINDINGS}

The theme of festivals was categorized into three subcategories of religious festivals, national festivals, and seasonal festivals. Table 1 shows these sub-themes together with the related categories.

As can be seen in Table 1, each sub-theme has its own categories. Religious festivals have three categories: specific cases for Ramadan festival, specific cases for sacrifice festival, and common cases. The sub-theme of national festivals had two categories: preparations and celebrations. The sub-theme of seasonal festival had two categories: Nowruz and Hidirellez.

\section{Findings About Religious Festivals}

As stated above, the religious festivals are found to have three categories: specific cases for Ramadan festival, specific cases for sacrifice festival, and common cases. Table 2 shows the subcategories of these categories. 


\section{Common Cases}

This category refers to common activities in both of the religious festivals. These are preparations and celebrations.

Preparation for festival. Before both of the religious festivals, houses were cleaned. The following reports exemplify this activity:

"Houses were whitewashed ten days before the festival. Cleaning was done. Doors and windows were cleaned" (Y1lmaz, personal communication, 2016).

"Before the festival, house was cleaned. House was whitewashed" (Atakan, personal communication, 2016).

"My mother cleaned the house before the festivals. She washed carpets. When it was winter, carpets were rubbed off' (Doğru, personal communication, 2016).

Another preparation for festival is shopping. New dresses were bought for all family members. When there were any engaged couples, their families bought new dresses for their future daughter-in-law or for their future son-in-law. Gifts were also bought to give elderly people visited. The following reports exemplify these activities:

"Men went shopping and bought dress" (Y1lmaz, personal communication, 2016).

"Dress was bought for festivals. We also bought shoes and socks, whatever we needed before festivals" (Doğru, personal communication, 2016).

"First we went shopping for festival. Dress or shoes. Gifts were also bought. These were brought to elder family members" (Akpürüm, personal communication, 2016).

"Before festivals, families bought dress for their son-in-law or daughter-in-law" (Akpürüm, personal communication, 2016).

"In festivals, families bought dress, shoes, and other items for their son-in-law or daughter-in-law" (Doğru, personal communication, 2016).

In festivals, various meals were prepared to offer guests. These included local meals such as su böreği (a type of patty), yogurt soup, stew, baklava, and rice. The following reports are about food tradition in festivals:

"The first one was su böreği (a type of patty). It should be done in every festival. Yogurt soup. Also stew. Baklava was always offered to each guest" (Yılmaz, personal communication, 2016).

"Sweet for festivals was baklava. In addition, sarma (a dish of grape, cabbage, monk's rhubarb or chard leaves rolled around a filling usually based on minced meat). All dish was prepared before the festival" (Doğru, personal communication, 2016).

Activities in the festival. In the morning of the first day of the festival, men, including boys, went to Morning Prayer. Then, they visited cemetery. These activities were limited to men. The related reports are given as follows:

"My father and I visited cemetery following Morning Prayer (Salat al Eid). We prayed for our relatives" (Erdinç, personal communication, 2016).

"We went to Morning Prayer (Salat al Eid). Then we visited cemetery" (Atakan, personal communication, 2016).

"In the morning of the first day of the festival men went to Morning Prayer (Salat al Eid)" (Doğru, personal communication, 2016).

"Fathers and sons went to Morning Prayer (Salat al Eid). Then they visited cemetery. Each dead relative was told to the children. Children were taught to visit cemetery" (Akpürüm, personal communication, 2016).

"Following the prayer, men visited cemetery. Women did not go there" (Y1lmaz, personal communication, 2016).

Following cemetery visit, family members celebrated the festival. Children kissed the hand of their parents. After breakfast, family members visited neighbours and relatives. They brought some gift to them such as chocolate and candy. Guests were offered drinks. They might be also given gifts such as socks and handkerchief. Little children might also be 
given money. Related reports are given as follows:

"Children kiss the hands of their parents. They may visit their aunts, uncles, and other relatives. They are given money. Adults may be given handkerchief or socks. Bringing gift to relatives is a must" (Y1lmaz, personal communication, 2016).

"Visits to neighbours. Candy is offered. Money, handkerchief are given" (Atakan, personal communication, 2016).

"The hands of parents are kissed. Following breakfast, elderly relatives are visited" (Doğru, personal communication, 2016).

"The hands of elderly are kissed. Each relative is visited. Several gifts, handkerchief and socks are given to guests. Children up to thirteen or fourteen years old are given money. Guests are offered dessert and seasonal drinks" (Akpürüm, personal communication, 2016).

\section{Specific Cases for Ramadan Festival}

Feast of Ramadan was found to have three categories: reading of Quran, fasting breaking dinner and Sahure, and Tarawih prayer.

Reading of Quran. Throughout Ramadan, Quran is read at houses of some people. One of the participants reported:

"Throughout Ramadan, Quran is read at houses. Anyone who wants to do it can do it" (Yilmaz, personal communication, 2016).

Fasting breaking dinner and Sahure. In Ramadan, it is common to invite people to fasting breaking dinner. Women prepare meal for Sahure.

"In Ramadan, it is very significant to invite people to fasting breaking dinner in Kütahya. The number of invited people may be 20-30" (Atakan, personal communication, 2016).

"In Ramadan, people are either invited to fasting breaking dinner or invite somebody to that dinner. It was not common to have that dinner with just family members" (Akpürüm, personal communication, 2016).
"Women wake up one hour before the pre-down meal in Ramadan. They mostly cook pancake with poppy. It is companied by fruit stew" (Atakan, personal communication, 2016).

Tarawih prayer. Women go to Tarawih prayer at homes. The following report is about it:

"Following fasting breaking dinner, Tarawih prayer took place at someone's house" (Yilmaz, personal communication, 2016).

\section{Specific Cases for Sacrifice Festival}

The festival of sacrifice was found to have two categories: sacrificing and sending sacrificial ram to the home of the future daughter-in-law.

Sacrificing. Sacrificing takes place following the celebration. A portion of the meat is distributed to those who are in need. These people are identified in advance. People do not eat anything until the meat is cooked. The following reports are about this topic:

"Following celebration, people sacrifice. Before the festival, those who are in need are identified. A portion of the meat is distributed to them. It is extremely important" (Akpürüm, personal communication, 2016).

"People sacrifice more than one animal if they are rich. Right side is distributed. The other side is kept at home" (Yilmaz, personal communication, 2016).

"We fest until the meat of the sacrificed animal is cooked" (Doğru, personal communication, 2016).

"They say that nobody should eat anything until the meat of the sacrificed animal is cooked. It is a habit" (Erdinç, personal communication, 2016).

Sending sacrificial ram to the home of the future daughter-in-law. If the family is rich, a sacrificial ram is sent to the home of the future daughter-in-law together with an amount of gold. In turn, the other family sends baklava or another dessert to the home of the future son-in-law. Related statements are given as follows:

"If the family is rich, a sacrificial ram is sent to the home of the future daughter-in-law together with an 
Table 3. Categories and Subcategories of National Festivals

\begin{tabular}{|l|l|l|}
\hline Sub-themes & Categories & Uubcategories \\
\hline \multirow{4}{*}{ National festivals } & \multirow{2}{*}{ Preparations } & Decorations \\
\cline { 2 - 3 } & \multirow{3}{*}{ Celebrations } & Preparations for activities \\
\cline { 3 - 3 } & & Venue \\
\cline { 3 - 3 } & Dress \\
\cline { 3 - 3 } & Activities \\
\hline
\end{tabular}

amount of gold. If it is not, it is not sent" (Y1lmaz, personal communication, 2016).

"Sending a ram is a must in the festival of sacrifice. In turn, they are offered other gifts" (Erdinç, personal communication, 2016).

"A huge ram is bought and sent to the home of daughter-in-law. A gold is put on the forehead of ram with a red ribbon. The ram is painted red. When the animal is sacrificed, the best portion is sent to the home of in-laws. Family of the daughter-in-law prepares baklava" (Atakan, personal communication, 2016).

"Ram is sent. In addition, a gold. It is attached to the horns of ram. In turn, baklava is sent" (Doğru, personal communication, 2016).

"Rich people send ram. They add a gold. It is a festival gift for the future daughter-in-law" (Akpürüm, personal communication, 2016).

\section{Findings About National Festivals}

The sub-theme of national festivals is found to have two categories: preparations and celebrations. Table 3 shows these categories.

Preparations. Preparations for national festivals are grouped into two categories: decorations and preparations for activities.

Decorations. In national festivals, streets and classrooms are decorated with flags. In some of the national festivals, shops are closed until afternoon. Statements by the participants are as follows:

"Flags are hanged in the streets" (Y1lmaz, personal communication, 2016).
"Everywhere is decorated with flags. Until afternoon, shops are closed" (Atakan, personal communication, 2016).

"Decorated with flags. Classrooms are decorated" (Akpürüm, personal communication, 2016).

Preparation for activities. Preparations for the activities begin long before the national festivals. These include the preparations of folk dance groups and students who will make demonstrations or read poems. The statements below exemplify these activities:

"Especially for April 23, they practice folk dances" (Doğru, personal communication, 2016).

"Bands are prepared. A month before the festival, several groups practice their activities at schools" (Erdinç, personal communication, 2016).

"For each festival, children memorize poetry. They learn about the origins of the festival" (Akpürüm, personal communication, 2016).

Celebrations. Celebrations for national festivals are grouped into three categories: venue, dress, and activities.

Venue. Festivals are mostly celebrated in stadiums. People watch the activities there. Related reports are given below:

"In the stadiums, celebrations are organized" (Doğru, personal communication, 2016).

"People went to stadiums to watch the activities" (Erdinç, personal communication, 2016).

"Celebrations are done in stadiums. Everybody go to stadiums" (Atakan, personal communication, 2016). 
"We went to stadium" (Akpürüm, personal communication, 2016).

Dress. In national festivals, children wear local clothes and military uniforms. The following statements exemplify it:

"We wore heavy dresses" (Yllmaz, personal communication, 2016).

"We wore nice dresses" (Doğru, personal communication, 2016).

"Children wore wedding dresses or military uniforms" (Erdinç, personal communication, 2016).

"We wore national clothes" (Atakan, personal communication, 2016).

Activities. In the national festivals, the common activities were found to be as follows: folk dances, military parade crossing, drama, and torchlight procession. The following reports exemplify these activities as follows:

"Folk dances. I played local folk dances. At night, there were torchlight procession" (Y1lmaz, personal communication, 2016).

"I remember August 30. Torchlight procession was organized. It was carried out by soldiers and it was very beautiful" (Doğru, personal communication, 2016).

"During military parade crossing, people applauded them. The war scenes were animated. Soldiers carried out torchlight procession at night" (Erdinç, personal communication, 2016).

"Folk dances were played. On a May 19 festival, I was in secondary school and we jumped over a fire chamber. In the Republic Day, local artists joined the parade" (Atakan, personal communication, 2016).

"We went to torchlight procession. Military parade crossing and other activities. All of them were very beautiful" (Akpürüm, personal communication, 2016).

\section{Findings About Seasonal Feasts}

Seasonal feasts are grouped into two categories: Nowruz and Hidırellez. Table 4 shows the categories under seasonal feasts.
Nowruz. According to the reports by the participants, the Nowruz celebrations are not common in Kütahya. Some participants reported that they never experienced such a celebration. Only two participants told some events about the Nowruz celebrations.

"I never joined the Nowruz celebrations. I do not have any information about it" (Doğru, personal communication, 2016).

"We do not know what Nowruz is" (Y1lmaz, personal communication, 2016).

"I do not know anything about the Nowruz celebrations in Kütahya and I have never experienced it" (Erdinç, personal communication, 2016).

Firing. People jump over fire in the Nowruz day. It is thought that Nowruz is originated from Iran. In Kütahya, Nowruz is known as Gevur Küfürü (infidel blasphemy). The related reports are given as follows:

"We collected wood from streets. We piled them on the streets. Then it was fired. We jumped over it. This festival came from Iran" (Atakan, personal communication, 2016).

"The beginning of spring was celebrated. It was called Gevur Küfürü (infidel blasphemy) here. We set fire and jumped over it. Nowruz meant only setting fire" (Akpürüm, personal communication, 2016).

Egg painting. In Nowruz, eggs are boiled and painted. The following reports exemplify these activities:

"We painted eggs using onionskin. We clinked them. Anyone who broke the other's egg ate it" (Atakan, personal communication, 2016).

Putting horns. In the day of Nowruz, people should wake up early. In order to reveal those who do not wake up early, horns are attached to their doors:

"We put horns to the doors of those who do not get up early" (Atakan, personal communication, 2016).

Hidırellez. Reports showed that in Kütahya the Hidirellez celebrations are much more frequent. The participants mostly narrated activities about it. 
Table 4. Categories and Subcategories of Seasonal Festivals

\begin{tabular}{|l|l|l|}
\hline Sub-themes & Categories & Subcategories \\
\hline \multirow{5}{*}{ Seasonal festivals } & \multirow{3}{*}{ Nowruz } & Firing \\
\cline { 2 - 3 } & & Egg painting \\
\cline { 2 - 3 } & & Putting horns \\
\hline \multirow{5}{*}{ Hidirellez } & Announcing with town criers \\
\cline { 3 - 3 } & & Egg painting \\
\cline { 3 - 3 } & & Putting tree branch \\
\hline & & Making wishes \\
\hline & & Entertainment \\
\hline
\end{tabular}

Announcing with town criers. A few days before Hidirellez, it is announced by town criers. It is told by a participant as follows:

"In May, town criers announce Hidirellez two or three days before it" (Atakan, personal communication, 2016).

Egg painting. As in Nowruz, in Hidirellez celebrations, eggs are boiled and painted. The following reports exemplify these activities:

"In the day, we boil eggs with onionskin. They become yellow. Then we eat eggs in the garden with our friends" (Atakan, personal communication, 2016).

"Eggs are painted. They are boiled. We go to the castle and there we play games with eggs" (Akpürüm, personal communication, 2016).

Putting tree branch near the doors. As in Nowruz, in Hidirellez, it is important to wake up early. Tree branches are put near to the doors where people do not wake up early. The related report is as follows:

"They hang tree branches on the door, you open and see it hanging on the door, because you wake up late" (Y1lmaz, personal communication, 2016).

Making wishes. In Hidirellez, people make wishes in varied ways. They mostly wish a house, a partner, a child, and money. The following reports exemplify these activities:

"Between evening prayer and Isha prayers, people make wishes in their garden. For instance, if they do not have a home, they put a picture of it there. They put the image of anything what they do not have. Then they hang a bag in which they put money on tree. In the morning, young girls come together and go to near water. They write their wishes on a paper and then throw it into the water" (Y1lmaz, personal communication, 2016).

"Under roses, people put anything that resembles to their wish. It is taken away before the morning prayer" (Doğru, personal communication, 2016).

"People put handkerchief to make a wish under a tree. They may also put some objects resembling their wish" (Erdinç, personal communication, 2016).

Entertainment. In Hidirellez, several recreational activities are organized. These include playing tambourines on the streets, skipping rope, going to picnics, and watching performances of acrobats. Furthermore, it is believed that shopping on that day will bring abundance. The related statements are given below:

"Games are played at night. Tambourines are played in the streets. People skip rope" (Yllmaz, personal communication, 2016).

"In Hidırellez, people go to picnic" (Doğru, personal communication, 2016).

"Acrobats come and make demonstrations. Shopping on that day is blessed. On that day, everyone buys sugar, rice, and salt. It is said that Hizır touched them" (Atakan, personal communication, 2016). 


\section{CONCLUSIONS}

The major findings of the study were given below. These findings were based on the reports of the informants.

\section{In Terms of Religious Festivals}

(1) Preparations before the festivals include cleaning, shopping, and preparing meals. In Kütahya, these preparations are similar to ones found in other regions. Alişar (1992) found that preparations begin three days before the festivals in İçel region. Uslu (1997) concluded that, in Yozgat and nearby regions, the preparations for the festivals begin a week before. Yüsküp (2007) stated that among Macedonia immigrants living in Sakarya, such preparations begin long before the festivals.

(2) In the morning of the first festival day, fathers go to prayer with their sons. Then they visit cemetery. Women do not join these visits. Such visits are done before the festival or on the first day of festival in the country and in other Turkic countries. For instance, in İçel region, such visits are done one day before the festival, but in some villages, it is done on the first festival day (Alişar 1992). The other findings are: in Kastamonu, visiting the cemeteries occurs one day before the festival and in Devrekâni, on the first festival day, the cemeteries are visited (Yüksel 2011); in Yozgat province, such visits are done either on the first festival day or one day before the festival (Uslu 1997); in Avşar villages of Pınarbaşı district of Kayseri province, such visits take place one day before the festival (Aslan 2011). Polat (2015) stated that Kyrgyz people visit cemetery both one day before the Ramadan and on the first day of the Ramadan festival. In Kütahya, some rituals are not found, which are seen among Turkish people such as bringing meal to the grave and putting a candle on the grave by Kyrgyz people (Kutlu 2007) and distributing some food (pretzels, raisins, chickpeas, and village bread) following the visit to the cemetery in Kastamonu
(Yüksel 2011).

(3) In festival visits, guests are given socks and handkerchief. Giving handkerchief as a gift in festivals was also common in other regions, but it is not common these days. On September 29, 2015, a website, Ünye Kent Gazetesi, published an article written by M. Canbulat about the topic. In the article, the reason for giving handkerchief as a gift was explained as follows: "sensitive people of the past did not want to show money they gave to children and they put money in handkerchief". Ankara supplement of Posta newspaper also published an article about the topic on September 26, 2015. It was stated that this tradition has lost due to the common use of paper handkerchief in the society.

(4) If the family is rich enough, they may send a sacrificial ram to the home of the future daughter-in-law. This tradition is also observed in other parts of Turkey, for instance, in Kastamonu (Yüksel 2011), in Avşar villages of Pınarbaşı district of Kayseri (Aslan 2011), in Çankırı (Varvar 2010), in Bursa (İlsan 2010), and among Georgians living in Sakarya (Kahramanca 2015).

\section{In Terms of National Festivals}

(1) Preparations begin long before. Streets are decorated with flags which signal the preparations.

(2) Celebrations mostly take place in stadiums. Children frequently wear authentic dress and military clothes. Common activities include folk dances, military band demonstrations, drama, and torchlight procession by soldiers at night.

(3) Compared to past celebrations of national festivals, it is seen that there are some differences in terms of manner and place of celebrations. It was found that national festivals were celebrated with much more enthusiasm and with much more people in the previous years.

\section{In Terms of Seasonal Festivals}

(1) Reports showed that the celebrations of Nowruz 
are rare in Kütahya. Some of the participants stated that they never involved in such celebrations. It is thought that this celebration is originated from Iran. In Kütahya, Nowruz celebrations are known as "Gevur Küfürü". The common activities are painting and clinking eggs and lighting a fire. Önal (2003) argued that in the places where people from different religious backgrounds live together, some protection steps are taken. For instance, for Turkish people, the Easter feast is seen as blasphemy. Similarly, Christians have a similar approach towards the festivals of Muslims. For instance, Hidirellez is called "the night of blasphemy" in Romania and Bulgaria. In Turkey (Afyon, Eskişehir, Manisa, and Muğla), it is called "infidel blasphemy". In the celebrations, people light a fire, jump over fire, and paint and clink eggs (Önal 2003). Similar to Christian customs for the Easter feast, in Iğdır, eggs are painted red in Nowruz. Eggs are painted green, yellow, and black in the Turkish Republic of Northern Cyprus (Küçük 2010). Given that Nowruz is regarded by the participants as "infidel blasphemy" in Kütahya, it can be said that Nowruz and blasphemy are confused. For Turkish people, fire is divine and respected. For them, fire is a stove and it refers to survive. Turkish people believe that fire comes from the sky. Therefore, it is divine and has power of purification (Kafkasyalı 2005). Therefore, in Nowruz, Turkish people jump over fire.

(2) Reports indicated that in Kütahya, Hidırellez is much more frequently celebrated in contrast to Nowruz. Painting and clinking eggs are also seen in the celebration of Hidirellez. For activities, areas near to water and green areas are preferred. Sezen (1999) stated that in Hidirellez, people go to wooded, watery, and greenery places, because that day, Hizır (an immortal person) comes when people are in time of need in such places. In the celebrations of Hidirellez, the tradition of making wishes is also seen in Kütahya as in other regions.

In the celebrations of festivals in Kütahya, some elements of Turkish belief system are seen, such as the cult of ancestors, the cult of fire, and the cult of water. For instance, cemetery visits are related to the cult of ancestors. Purification through jumping over fire is related to the cult of fire. The cult of water is seen in going near to water and making wishes there.

Participants stated that many festival traditions have disappeared and that young people are not fully aware of them. Festivals are functional in social unity. Festivals have a significant role for next generations to acquire cultural values. Best ways to transmit cultural values are to have some experiences about them and to try to make them alive. Families, educational institutions, and public institutions have important functions in this regard.

\section{References}

Akbulut, D. A. 1995. "Samsun's 'The Day of Gazi' or 19th May Festival." Ataturk Research Center Journal 6(33):771-779.

Alişar, F. 1992. "Festivals and Religion Festival Traditional in İçel." National Folklore-The Journal of International Culture Researches 2(15):29-30.

Aras, E. 2002. "Turks Hidrellez Tradition." National Folklore-The Journal of International Culture Researches 7(54):39-54.

Araz, N., U. Günay, N. Tan, K. Toygar, E. Öksüz, and B. Seyidoğlu. 1997. Our Traditions (Turkish Morals) on the Verge of 21st Century. Ankara: T. C. Başbakanlık Aile Araştırma Kurumu Yayınları.

Artun, E. 2011. Ceremonies and Festivals at Folk Culture of Çukurova. Çukurova University Turcology Research Center. Retrieved February 1, 2016 (http://turkoloji.cu.edu. tr/HALKBILIM/erman_artun_cukurova_toren_bayram_sen likler.pdf).

Aslan, M. G. 2011. "District of Kayseri Province Pınarbaşı Avşar Villages of Turkish Folk Beliefs." Master thesis, Niğde University, Turkey.

Christensen, L. B., R. B. Johnson, and L. A. Turner. 2015. Research Methods, Design and Analysis. Ankara: An1 Yayınc1lı.

Clandinin, D. J. and F. M. Connelly. 2000. Narrative Inquiry: Experience and Story in Qualitative Research. San Francisco: Jossey-Bass.

Çobanoğlu, Ö. 2000. "Nowruz and Hidrellez as Part of Traditional Festivals." Türkbilig, Journal of Turcology Researches 1:51-59. 
Connelly, F. M. and D. J. Clandinin. 1990. "Stories of Experience and Narrative Inquiry." Educational Researcher 19(5):2-14.

Fraenkel, J. R., N. E. Wallen, and H. H. Hyun. 2011. How to Design and Evaluate Research in Education. New York: McGraw-Hill.

Gömeç, S. 2006. Essentials of Turkish Culture. Ankara: Akçağ Yayınlar1.

Günay, U. 1995. "Rituals and Hidirellez." National Folklore-The Journal of International Culture Researches 26:2-3.

Güzel, A. and A. Torun. 2005. Turkish Folk Literature Hand Book. Ankara: Akçağ Yayınları.

İlsan, D. 2010. "Wedding Dresses in the District of Bursa." Master thesis, Marmara University, Turkey.

Kafkasyal1, A. 2005. "A Glance at Nowruz Tradition in Turkish World." Ataturk University Journal of Social Sciences Institute 6(2):149-172.

Kahramanca, H. 2015. "Marriage Tradition of Georgians Who Living in Sakarya." Master thesis, Abant İzzet Baysal University, Turkey.

Kear, T. M. 2012. "The Use of Narrative Analysis to Study Transformative Learning in Associate Degree Nursing Students: A Focus on the Methodology." Teaching and Learning in Nursing 7:32-35.

Koca, S. 2004. "Festivals in Old Turks." P. 25 in The Encyclopedia of Turkish World Nowruz. Ankara: Atatürk Kültür Merkezi Başkanlığı Yayınları.

Küçük, S. 2010. "The Concept of Colour in Ancient Turkish Culture." Bilig-Journal of Social Sciences of the Turkic World 54:185-210.

Kütahya Valiliği (Kütahya Governorship). 2016. Historically. Retrieved February 12, 2016 (http://www.kutahya.gov.tr/ tarihce).

Kutlu, S. 2007. "Ramadan and Religious Festivals in Kyrgyzstan." Turkish Culture and Hacl Bektash Veli Research Quarterly 42:1-32.

Merriam, S. B. 2013. Qualitative Research-A Guide to Design and Implementation. Ankara: Nobel Akademik Yayıncilık.

Oğuz, M. Ö. 2005. "Intangible Cultural Heritage: Nauruz/New Day in Turkey." National Folklore-The Journal of International Culture Researches 9(65):5-16.

Önal, M. N. 2003. "A Forgotten Tradition: The Ceremony of Curse Evenings." National Folklore-The Journal of International Culture Researches 60:128-134.

Onarl1, İ. 2003. "Nowruz Festival." Turkish Culture and Hacl Bektash Veli Research Quarterly 25:1-43.

Özçelik, M. 2011. "The Emergence of 23 April Children's Day and the Celebrations From 1922 to 1929." Gazi Academic View 5(9):265-284.

Özdemir, N. 1999. "The Concept of Fun and Celebrations of
H1direllez." National Folklore-The Journal of International Culture Researches 42:31-35.

- 2006. "Renew (Regenerate) and Nowruz." National Folklore-The Journal of International Culture Researches 69:15-27.

Polat, K. 2015. "Ramadan and Eid Activities in Kyrgyz." A $\breve{g r} r$ Ibrahim Çeçen University Journal of Social Science Institute 1(1):25-48.

Posta Ankara. 2015. Forgotten Handkerchief Tradition. Retrieved June 3, 2016 (http://gold.ajanspress.com.tr/link press/vrAZ79_KS_jXBz3-XFjXDQ2/?v=2\&s=42611\&b=0 \&isH=1).

Sakaoğlu, S. and A. B. Alptekin. 2004. "Nowruz in Turkey." Pp. 379-408 in The Encyclopedia of Turkish World Nowruz. Ankara: Atatürk Kültür Merkezi Başkanlığı Yayınları.

Sandelowski, M. 1991. "Telling Stories: Narrative Approaches in Qualitative Research." IMAGE: Journal of Nursing Scholarship 23(3):161-166.

Sezen, L. 1992. "Hidırellez in Turkish Folklore." National Folklore-The Journal of International Culture Researches 14:32-33.

—. 1999. "Spring Festivals (Nowruz-Hidrellez)." Ataturk University Journal of Turkish Research Institute 12:81-86.

Tanfer, M. V. 1997. "The Festivals, Ataturk's Gift to Turkish Nation." The Journal of Ataturk Research Center 13(39):1039-1052.

Turan, F. A. 2008. "The Beliefs, the Rituals, the Prohibitions and the Sanctions in the Hidrellez "The May Sixth Festival'." Gazi Turkic Studies-Journal of Turkology Research 2:101-111.

Uca, A. 2007. "In the Turkish Society Nowruz-II." Ataturk University Journal of Turkish Research Institute $33: 151-182$.

UNESCO. 2009. Decision of the Intergovernmental Committee: 4.COM 13.03. Retrieved February 3, 2016 (http://www. unescoorg/culture/ich/en/decisions/4.COM/13.03).

United Nations. 2010. International Day of Nowruz 21 March. Retrieved February 3, 2016 (http://www.un.org/en/events/ nowruzday/).

Ünye City Newspaper. 2015. To Live Traditions: Forgetten Festival Handkerchief. Retrieved June 3, 2016 (http://www. unyekent.com/haber/40087/unutulan-bayram-mendili-gelen egini-yasatiyor).

Uslu, M. 1997. "Preparing Religious Festivals Celebration and Visiting Cemeteries in Yozgat." National Folklore-The Journal of International Culture Researches 33:139-144.

Uzun, H. 2010. "A Festival Made by National Will: The Celebration of 19 May the Commemoration of Atatürk, Youth and Sports Day." Journal of the Black Sea Studies 6(24):109-125. 
Varvar, M. 2010. "Tradition of Henna Night, Engagement and Wedding Ceremony in Çankırı." Master thesis, Gazi University, Turkey.

Yamanlar, E. 2000. The History of Civilization. Ankara: Gündüz Eğitim ve Yayıncılık.

Yildiz, N. 2004. "Denotation of Nowruz." P. 37 in The Encyclopedia of Turkish World Nowruz. Ankara: Atatürk Kültür Merkezi Başkanlığı Yayınları.

Yüksel, G. 2011. "Traditions of Celebrating Religious Festivals in Kastamonu and the Impacts of These Traditions on Human Interactions." Academic Sight International Refereed Online Journal of Social Sciences 26:1-26.

Yüksel, H. A. 2011. "The Tradition and Celebrations of Nawruz in Zenica." National Folklore-The Journal of International Culture Researches 89:271-275.
Yüsküp, D. 2007. "The Review Custom and Beliefs in Macedonian Emigrants Which Live in Sakarya." Master thesis, Sakarya University, Turkey.

\section{Bios}

Nil Duban, Ph.D., associate professor, Department of Elementary Education, Afyon Kocatepe University, Turkey; research fields: teacher training, primary education, values education, qualitative research methods.

Ramazan Yıldırım, doctoral student at Graduate School of Social Sciences, Afyon Kocatepe University, a teacher at Kütahya Yoncalı Vocational and Technical Anatolian High School, Turkey; research field: social sciences education. 